OPEN ACCESS

Edited by:

Maria J. Stangou, Aristotle University of

Thessaloniki, Greece

Reviewed by:

Natalia Stepanova,

SI "Institute of Nephrology National Academy of Medical Science of

Ukraine", Ukraine

Erasmia Sampani,

Hippokration General Hospital

Thessaloniki Greece, Greece

*Correspondence:

Michiel G. H. Betjes

m.g.h.betjes@erasmusmc.nl

Specialty section:

This article was submitted to

Nephrology,

a section of the journal

Frontiers in Medicine

Received: 03 March 2021

Accepted: 22 March 2021

Published: 14 April 2021

Citation:

Betjes MGH (2021)

Uremia-Associated Immunological Aging and Severity of COVID-19 Infection. Front. Med. 8:675573. doi: 10.3389/fmed.2021.675573

\section{Uremia-Associated Immunological Aging and Severity of COVID-19 Infection}

\author{
Michiel G. H. Betjes* \\ Division of Nephrology and Transplantation, Department of Internal Medicine, Erasmus Medical Centre, Rotterdam, \\ Netherlands
}

One year after the start of the COVID-19 pandemic it has become clear that some groups of individuals are at particular high risk of a complicated course of infection resulting in high morbidity and mortality. Two specific risk factors are most prominent, old age and the presence of co-morbidity. Recent studies have shown that patients with compromised renal function, especially those treated with renal replacement therapy or having received a kidney transplant are at a much higher risk for severe COVID infection and increased mortality. This may be in part due to the increased prevalence of co-morbid conditions in these patients but specific alterations in their immune system, reflecting premature immunological aging, may be equally important. In this review the different aspects, in particular thymus function and memory $T$ cell expansion, of uremia-associated immunological aging are reviewed with respect to COVID 19 infection. In essence, the decreased generation of naïve T cells may be instrumental in suboptimal anti-viral immune responses while the relatively uncontrolled expansion of effector $T$ cells may facilitate the feared phase of the COVID-19 infection with excessive and live-threatening inflammation of the lung parenchyma.

Keywords: uremia, chronic kidney disease, thymus, adaptive immunity, lymphopenia, immunological aging, COVID-19

\section{UREMIA-ASSOCIATED IMMUNOLOGICAL AGING \\ General Aspects}

End-stage renal disease is associated with increased risks for infections, cancer and a poor vaccination response to vaccines like Hepatitis B surface antigen (HBsAg) (1). The accumulation of uremic toxins and increased oxidative stress leads to a pro-inflammatory state which is believed to underlie the impaired immune system. Uremia affects all aspects of both the innate and adaptive immune system [reviewed in (1)]. Cell numbers of innate immune cells like monocytes and granulocytes are normal to increased. However, these cells have a more activated profile with expansion of, for example, the subset of pro-inflammatory monocytes CD14posCD16pos while their functionality may be comprised $(2,3)$. Dendritic cells are professional antigen presenting cells and at the crossroad of the innate and adaptive immune response. In particular the subset of lymphoid dendritic cells is affected by aging and uremia as opposed to the myeloid dendritic cells (4-7). These lymphoid dendritic cells produce large amounts of type 1 interferon and are key for adequate antiviral responses (8). In addition, there are less dendritic cells present in the skin and circulation which may contribute to a less efficient adaptive immune response $(5,9)$. 
Progressive lymphopenia with relatively more highly differentiated memory $\mathrm{T}$ cells is observed in association with more advanced stages of chronic kidney failure (10-12). Tracking the anti-HBsAg $\mathrm{T}$ cells after vaccination in patients with renal failure showed an insufficient $\mathrm{CD} 4 \mathrm{~T}$ cell response which correlated closely with an impaired serological response (13).

The changes within the adaptive immune system and consequences for immune responses closely resembles the effects of aging (Figure 1) (14). A shift in favor of myeloid vs. lymphoid precursor hematological stem cells in the bone marrow may be important (15). This process is driven by epigenetics which in turn is under the influence of systemic inflammation and oxidative stress as observed in end-stage renal failure $(16,17)$. However, the adaptive immune system is more broadly affected by aging with thymus involution as a major cause of a decreasing output of naïve $\mathrm{T}$ cells, in combination with increasing numbers of memory $\mathrm{T}$ cells and changes in the regulatory $\mathrm{T}$ cell compartment. The first two observations are consistently found in the elderly and patients with end-stage renal failure. The expansion of memory $\mathrm{T}$ cells in elderly individuals is usually associated with a slight increases in markers of systemic inflammation and therefore frequently named inflamm-aging (18).

The $\mathrm{T}$ cell system is studied the most intense in aging research as peripheral blood is an easily accessible source of abundant $\mathrm{T}$ cells and many assays are available to study phenotype, differentiation status and function of $\mathrm{T}$ cells. In fact, such an integrative analysis of the $\mathrm{T}$ cell system of ESRD patients showed immunological aging by an average of 15-20 years, meaning that the composition of the population of circulating $\mathrm{T}$ cells of a 50-year old hemodialysis patient resembles that of a 70 -year old healthy individual $(11,19)$. Of note, the interindividual variation is substantial and for instance individuals with a genetic background of longevity show less signs of immunological aging (20).

\section{Thymus Function and Aging}

The thymus is important in producing naïve T cells which all have a specific $\mathrm{T}$ cell receptor (21). Naïve T cells leaving the thymus are called recent thymus emigrants (RTE) and were positively selected for the capacity to interact with the HLA molecules of the antigen-presenting cells but deleted if this interaction was to strong, thereby preventing potential dangerous autoreactivity. In addition, regulatory $\mathrm{T}$ cells (Tregs) are also generated which are called natural Tregs (22). Essentially, the thymus continuously generates the enormous diversity of $\mathrm{T}$ cell receptors which is needed to combat efficiently the wide variety of pathogens that may be encountered while controlling autoreactive T cells (23).

Aging is invariably associated with involution of the thymus leading to a steady decline in RTEs. The RTEs can be detected in the circulation by, for example, expression of CD31 on naïve $\mathrm{T}$ cells and there is on average an almost linear relationship between decreasing numbers of CD31 positive naïve T cells and age (24, 25). Homeostatic proliferation, particularly of CD4 naïve T cells, is able to maintain the volume of the naïve $\mathrm{T}$ cell compartment but naïve CD8 T cells become severely depleted in the elderly (26-29). This may lead to a contraction of the TCR repertoire which in turn can limit the diversity and thereby the efficacy of

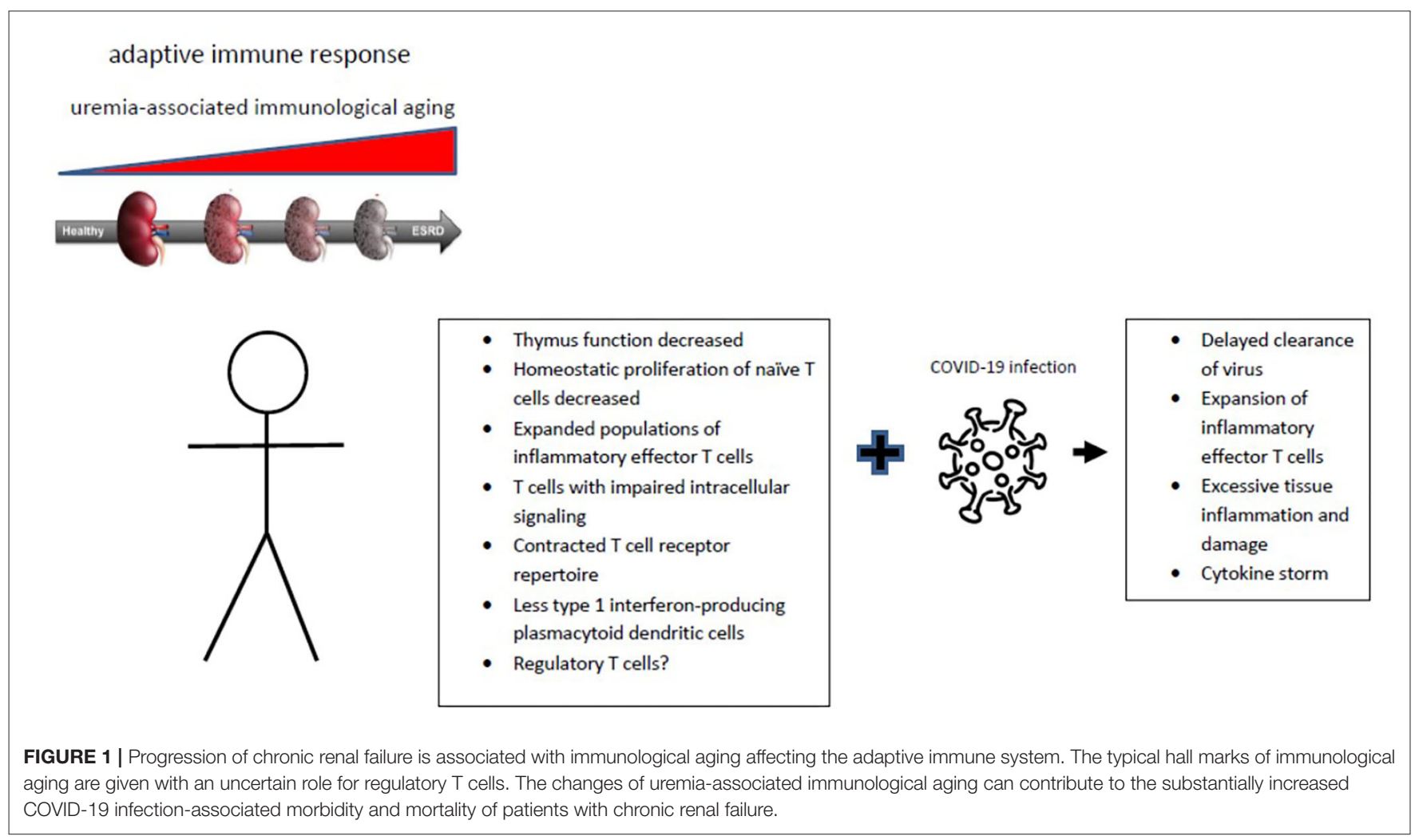


the immunological response (30). For instance, thymus output is crucial in the formation of protective immune responses during the early formation of a Salmonella infection but is dispensable once persistent Salmonella infection is established (31). Whether the output of natural Tregs is in line with the decrease in RTE's is not known.

Progressive severity of renal failure is associated with decreased numbers of naïve $\mathrm{T}$ cells which can be attributed to both a decrease in RTE's and a decrease in compensatory homeostatic proliferation $(11,32,33)$. Activation-induced cell death of naïve $\mathrm{T}$ cells is increased and likely underlies part of the pathogenesis (11). As a result, at all decades of life end-stage renal failure results in a significant contraction of the circulating naïve $\mathrm{T}$ cell compartment $(33,34)$. Recent studies have shown that lymphoid and non-lymphoid tissues may also harbor naïve $\mathrm{T}$ cells and the relation with circulating naïve $\mathrm{T}$ cells is not clearly established $(28,35)$. However, comparing the percentage of lymph node naïve $\mathrm{T}$ cells with the percentage of peripheral blood naïve $\mathrm{T}$ cells showed a very close correlation (36).

Why the production of RTE's is affected by uremia is not known but from animal experiments it is clear that loss of renal function leads to volume loss of lymphoid organs like the thymus (37). The thymus and in particular the thymus epithelial cells appear to be very sensitive for inflammatory and oxidative stress which translates into an increased tendency for apoptosis (38-43). This may not only explain the thymus involution with normal aging, as a result of prolonged and variable exposure to these conditions, but also the uremia-associated decrease in thymus function in parallel with the increased pro-inflammatory environment observed with progressive loss of renal function.

Naïve $\mathrm{T}$ cell numbers in both healthy individuals as in recipients of kidney transplants were independently associated with all-cause mortality $(19,33,44)$. Although this implies a causal relationship, this is not without uncertainty. Life events leading to episodes of increased inflammation and oxidative stress could accelerated thymus involution leading to "low for age" numbers of naïve $\mathrm{T}$ cells but also have a broad negative impact on the physical robustness of an individual. Therefore, the possibility exists that low naïve $\mathrm{T}$ cell numbers not only contribute to a weakened immune system but also point to a life history with harmful events leading to frailty (45-47).

\section{Memory T Cell Expansion and Immunological Aging}

The second hall mark of an aged $\mathrm{T}$ cell system is the expansion of memory $\mathrm{T}$ cells which may show signs of senescence and/or exhaustion which can be defined as the loss of proliferative capacity and specific effector functions like cytokine production and cytotoxicity (48). The increased numbers of memory $\mathrm{T}$ cells arise during life as a natural consequence of an immune system that has reacted to specific pathogens. When infections persist, like chronic hepatitis C or HIV, it may lead to progressive differentiation of virus-specific memory $\mathrm{T}$ cells into senescence and susceptibility for cell death (49-51). With increasing age, the memory $\mathrm{T}$ cells have undergone many rounds of replication with consequent shortening of their telomeres (52).
Measuring telomere length therefore provides another measure of immunological aging (11).

Expansion of particular populations of memory $\mathrm{T}$ cells in the elderly persons may lead to a skewed TcR repertoire and may cause gaps in the TcR repertoire (53-56). The latter could fit in the concept of immunological space, which postulates that the immune system can only support the survival of a certain quantity of immune cells $(57,58)$. Of note, in recent years it has become evident that all tissues harbor a large quantity of resident $\mathrm{T}$ cells that do not circulate and that provide local protection against pathogens (59). As a first line of defense, the resident $\mathrm{T}$ cells are enriched in antigen-specific $\mathrm{T}$ cells that react to pathogens which are frequently encountered within that tissue, for example influenza-specific $T$ cells in the lungs $(60,61)$. In contrast, relatively few highly differentiated $\mathrm{T}$ cells are present in the lymph nodes (36). Thus, the population of circulating $\mathrm{T}$ cells is only one of the many compartments of T cells, but easy to monitor and in general reflecting an ongoing immune response by increased frequencies of antigen-specific T cells.

Several studies have shown that an expanded population of differentiated effector memory $\mathrm{T}$ cells which have lost the expression of the co-stimulatory molecule CD28 is associated with less efficient vaccination and a decreased risk for rejection after kidney transplantation (14, 62-65). The underlying mechanisms may be multiple as the pool of CD28null T cells harbors many different cell types including senescent $\mathrm{T}$ cell and cells with a regulatory function $(66,67)$.

Circulating numbers of natural Tregs may increase with age as a result of an expanded population of memory Tregs. These inflated numbers of Tregs in the elderly can limit immune responses like vaccination response to influenza but could also foster autoimmunity and chronic inflammation (68). Chronic renal failure per se does not affect numbers and function of circulating natural Tregs (69).

Of interest is the observation from animal experiments and young adults after thymectomy at childhood, that lower numbers of naïve $\mathrm{T}$ cells facilitate an expansion of circulating memory $\mathrm{T}$ cells which may be a relevant phenomenon in immunological aging (70-72).

In patients with chronic renal failure the immunological aging of the memory $\mathrm{T}$ cells is more advanced as can be shown by the increased reduction in $\mathrm{T}$ cell telomere length and a higher frequency of highly differentiated $\mathrm{T}$ cells $(2,11,19,73)$. In addition, as in healthy individuals, the important intracellular signal pathway involving the MAP kinases ERK, p38 and DUSP6 is unfavorably changed by aging $(74,75)$.

\section{IMPLICATIONS FOR COVID-19 INFECTION}

Increasing morbidity and mortality associated with COVID-19 infection is highly associated with elderly age and co-morbid conditions (76). Patients on dialysis, with CKD and recipients of organ transplant represented three of the four comorbidities associated with the highest mortality risk from COVID-19 (77). Most likely, this is at least in part associated with their prematurely aged immune system as a coordinated adaptive $\mathrm{T}$ 
cell response is associated with less severity of disease (78). Of note, changes at many levels of the immune system other than the adaptive $\mathrm{T}$ cell response have been described in association with aging and could contribute to severity of COVID-19 infection, but their relative importance has as yet not been established.

Fatality of COVID-19 infection is highly associated with a dysregulated immune response with progressive and severe inflammation of the lung parenchyma leading to extreme hypoxia (79-81). Several mutually not exclusive scenarios may lead to this outcome in the context of immunological aging. First, the aged immune system may be slow or inefficiently responding to this new viral pathogen as a result of a contracted TcR repertoire in the naïve $\mathrm{T}$ cell population and a general decline in $\mathrm{T}$ cell function by less effective intracellular signaling. In addition, the decreased numbers of plasmocytoid dendritic cells may have a profound negative effect on viral control as type 1 interferon is important in COVID-19 clearance in an experimental hamster model of infection (82).

Both deficiencies would lead to delayed clearance of the virus and prolonged stimulation and expansion of memory $\mathrm{T}$ cells that are COVID-19 reactive. On average lower numbers of $\mathrm{T}$ cells have been found in hospital-admitted COVID-19 patients and lower cell numbers, specifically naïve T cells, are related to disease severity $(78,83-88)$. Although of considerable interest, these observations are most likely caused by the COVID-19 infection itself which leads to decreased $\mathrm{T}$ cell numbers which may restore with clinical improvement $(85,89)$.

Second, immunological aging can lead to a $\mathrm{T}$ cell system prone to expansion of highly reactive memory $\mathrm{T}$ cells as regulation by Tregs is less efficient, low numbers of naïve $\mathrm{T}$ cells facilitate such a response and time to resolution of the viral infection is relatively slow. This scenario is not just hypothetical as shown by the large number of studies on infection with cytomegalovirus. Infection with this herpes virus typically leads to a strong $\mathrm{T}$ cell immune response which can be recognized by an expansion in the peripheral blood of both highly differentiated memory CD8 and CD4T cells $(90,91)$. The CMV reactive CD4 T cells can be readily detected as they are negative for the costimulatory molecule CD28 (CD4posCD28null T cells)(90). Both the infectious dose and the age of the individual are related to the expansion of CMV-specific memory T cells $(92,93)$. Specifically, in elderly patients with chronic renal failure the expansion of CD4posCD28null T cells which normally comprise $<1 \%$ of the CD4 T cell population may be such that over $50 \%$ of CD4 T cells become CD28null $(94,95)$. The CD4posCD28null T cells are highly cytotoxic and express the chemokine receptor CXCR3 which allows for migration over endothelial cells (96). These cells are not without harm as they have been identified as a non-classical risk factor for atherosclerotic disease probably by their capacity to destabilize atherosclerotic plaques $(97,98)$. Thus, CMV infection in immunologically aged individuals like patients with chronic renal failure may cause poorly controlled memory $\mathrm{T}$ cell expansion with subsequent collateral damage in patients with atherosclerotic plaques.

Such an exaggerated and harmful T cell immune response in elderly COVID-19 patients with a severe course of disease is of course much more acute and intense leading to expansion of highly activated memory $\mathrm{T}$ cells in association with a cytokine storm (88). In the case of COVID-19 the large expansion of highly reactive effector $\mathrm{T}$ cells is likely primarily present in the lung parenchyma as has, for example, been shown for influenzaspecific T cells. Therefore, peripheral blood COVID-19 antigenspecific $\mathrm{T}$ cells are a reflection of the intensity of the immune response which may show different characteristics and may be much worse at the tissue level (99-102).

In the case of severe COVID-19 infection, controlling the inflammatory response by high dose steroid is currently the best option (103). A recent study among recipients of a liver transplant with COVID-19 infection showed that the use of tacrolimus was associated with a significant reduction of mortality (104). This findings underlines that limiting the excessive $\mathrm{T}$ cell response, in this case by tacrolimus, is a key element in harnessing the morbidity and mortality of COVID-19.

\section{THERAPEUTIC STRATEGIES TO INFLUENCE UREMIA-ASSOCIATED IMMUNOLOGICAL AGING}

Reversing immunological aging in humans is currently not possible although some interventions may be beneficial $(40,105)$. As thymus involution underlies ever decreasing naïve $\mathrm{T}$ cell numbers with aging and possible contributes to memory $\mathrm{T}$ cell expansion it would be of prime importance to control this process. The biological process of thymus involution is now better understood and it is clear that loss of thymus epithelial cells is essential.

Recent studies have shown that thymus involution involves the aging of the stromal microenvironment formed by thymus epithelial cells (TEC)(105). Many factors like cytokines, sex steroids and transcription factors are likely involved in TEC aging (106). Expression of the TEC autonomous transcription factor FOXN1 is pivotal for differentiation and maintaining TEC integrity. A null mutation of FOXN1 in mice results in a lack of hair and thymus, and gradual excision of FOXN1 over time in an experimental model results in thymus involution $(107,108)$.

This process can be favorably attenuated by transfecting thymus cells with FOXN1(70) and cellular therapy with FOXN1 producing stem cells or cytokine-to-TEC-based therapies using IL-22 or keratinocyte growth factor have shown promising results in experimental models. These approaches offer at least proof of the concept that thymus function can be (partially) restored (106).

Interleukin 7 is an important cytokine for $\mathrm{T}$ cell proliferation and homeostasis. Administration of recombinant IL-7 in humans appears to be safe and increases peripheral $\mathrm{T}$ cell numbers. However, there is little direct impact on thymus function which limits its use as a regenerative cytokine for the involuted thymus (109). Of interest, targeting of IL-7 to the thymus, for example, by a plasmid-delivered IL-7 fusion protein, was able to restore the thymus architecture and cellularity in aged animals (110).

Restoring renal function by kidney transplantation leads to a rapid clearance of inflammatory cytokines and relieves oxidative stress in ESRD patients. However, there is no reversal 
in any of the markers of $\mathrm{T}$ cell aging even at 1 year after transplantation (111). Thus, once established, thymus involution seems irreversible, leaving the ESRD patient with premature aging at a persistent increased risk for mortality, even after regaining adequate renal function with a GFR over $60 \mathrm{~mL} / \mathrm{min}$. The underlying mechanisms are likely epigenetic changes induced by any combination of inflammation and oxidative stress associated with uremia, which are not easily reversible (1).

Of considerable interest is a recent observation that a healthy lifestyle may slow down thymus involution. Smoking and obesity are associated with fattening of the thymus (112) and bariatric surgery can partly reverse immunological aging (113). An observational study showed that elderly individuals with a high intensity of daily exercise had a better preservation of thymus function and less senescence of their immune system $(114,115)$. Having a healthy lifestyle with sufficient exercise will likely not reverse an atrophied thymus in ESRD patients but may delay further involution. Differences in lifestyle may also be part of the explanation for the substantial inter-individual variation

\section{REFERENCES}

1. Betjes MG. Immune cell dysfunction and inflammation in end-stage renal disease. Nat Rev Nephrol. (2013) 9:255-65. doi: 10.1038/nrneph.2013.44

2. Chiu YL, Shu KH, Yang FJ, Chou TY, Chen PM, Lay FY, et al. A comprehensive characterization of aggravated aging-related changes in $\mathrm{T}$ lymphocytes and monocytes in end-stage renal disease: the iESRD study. Immun Ageing. (2018) 15:27. doi: 10.1186/s12979-018-0131-x

3. Girndt M, Trojanowicz B, Ulrich C. Monocytes in uremia. Toxins. (2020) 12:340. doi: 10.3390/toxins12050340

4. Jing Y, Shaheen E, Drake RR, Chen N, Gravenstein S, Deng Y. Aging is associated with a numerical and functional decline in plasmacytoid dendritic cells, whereas myeloid dendritic cells are relatively unaltered in human peripheral blood. Hum Immunol. (2009) 70:777-84. doi: 10.1016/j.humimm.2009.07.005

5. Hesselink DA, Betjes MG, Verkade MA, Athanassopoulos P, Baan CC, Weimar W. The effects of chronic kidney disease and renal replacement therapy on circulating dendritic cells. Nephrol Dial Transplant. (2005) 20:1868-73. doi: 10.1093/ndt/gfh897

6. Lim WH, Kireta S, Russ GR, Coates PT. Uremia impairs blood dendritic cell function in hemodialysis patients. Kidney Int. (2007) 71:112231. doi: 10.1038/sj.ki.5002196

7. Pérez-Cabezas B, Naranjo-Gómez M, Fernández MA, Grífols JR, Pujol-Borrell R, Borràs FE. Reduced numbers of plasmacytoid dendritic cells in aged blood donors. Exp Gerontol. (2007) 42:1033-8. doi: 10.1016/j.exger.2007.05.010

8. Reizis B. Plasmacytoid dendritic cells: development, regulation, and function. Immunity. (2019) 50:37-50. doi: 10.1016/j.immuni.2018.12.027

9. Mettang T, Fritz P, Weber J, Machleidt C, Hubel E, Kiefer T, et al. Epidermal Langerhans cells in uremic patients on hemodialysis or continuous ambulatory peritoneal dialysis. Nephron. (1993) 65:27883. doi: $10.1159 / 000187488$

10. Litjens NH, van Druningen CJ, Betjes MG. Progressive loss of renal function is associated with activation and depletion of naive $\mathrm{T}$ lymphocytes. Clin Immunol. (2006) 118:83-91. doi: 10.1016/j.clim.2005.09.007

11. Betjes MG, Langerak AW, van der Spek A, de Wit EA, Litjens NH. Premature aging of circulating $\mathrm{T}$ cells in patients with end-stage renal disease. Kidney Int. (2011) 80:208-17. doi: 10.1038/ki.2011.110

12. Yoon JW, Gollapudi S, Pahl MV, Vaziri ND. Naive and central memory T-cell lymphopenia in end-stage renal disease. Kidney Int. (2006) 70:3716. doi: 10.1038/sj.ki.5001550 observed at every decade of life in the number of naïve $\mathrm{T}$ cells and RTE's.

\section{CONCLUSION}

Aging of the T cell system has specific hall marks and is largely characterized by a progressive decrease of thymus function and expansion of highly differentiated memory $\mathrm{T}$ cells. Patients with renal failure, even after successful kidney transplantation may have severe premature immunological aging in particular in association with CMV infection. Immunological aging may explain why severity of COVID-19 infection is both age dependent and significantly increased in patients with chronic renal failure.

\section{AUTHOR CONTRIBUTIONS}

The author confirms being the sole contributor of this work and has approved it for publication.
13. Litjens $\mathrm{NH}$, Huisman $\mathrm{M}$, van den Dorpel $\mathrm{M}$, Betjes MG. Impaired immune responses and antigen-specific memory CD4+ $\mathrm{T}$ cells in hemodialysis patients. J Am Soc Nephrol. (2008) 19:1483-90. doi: 10.1681/ASN.2007090971

14. Crooke SN, Ovsyannikova IG, Poland GA, Kennedy RB. Immunosenescence and human vaccine immune responses. Immun Ageing. (2019) 16:25. doi: 10.1186/s12979-019-0164-9

15. Cho RH, Sieburg HB, Muller-Sieburg CE. A new mechanism for the aging of hematopoietic stem cells: aging changes the clonal composition of the stem cell compartment but not individual stem cells. Blood. (2008) 111:555361. doi: 10.1182/blood-2007-11-123547

16. Vaziri ND. Oxidative stress in uremia: nature, mechanisms, and potential consequences. Semin Nephrol. (2004) 24:46973. doi: 10.1016/j.semnephrol.2004.06.026

17. Cohen G. Immune dysfunction in uremia 2020. Toxins. (2020) 12:439. doi: 10.3390/toxins12070439

18. Koelman L, Pivovarova-Ramich O, Pfeiffer AFH, Grune T, Aleksandrova K. Cytokines for evaluation of chronic inflammatory status in ageing research: reliability and phenotypic characterisation. Immun Ageing. (2019) 16:11. doi: 10.1186/s12979-019-0151-1

19. Crepin T, Legendre M, Carron C, Vachey C, Courivaud C, Rebibou $\mathrm{JM}$, et al. Uraemia-induced immune senescence and clinical outcomes in chronic kidney disease patients. Nephrol Dial Transplant. (2020) 35:62432. doi: $10.1093 /$ ndt/gfy 276

20. Derhovanessian E, Maier AB, Beck R, Jahn G, Hähnel K, Slagboom PE, et al. Hallmark features of immunosenescence are absent in familial longevity. $J$ Immunol. (2010) 185:4618-24. doi: 10.4049/jimmunol.1001629

21. Thapa P, Farber DL. The role of the thymus in the immune response. Thorac Surg Clin. (2019) 29:123-31. doi: 10.1016/j.thorsurg.2018.12.001

22. Cebula A, Seweryn M, Rempala GA, Pabla SS, McIndoe RA, Denning $\mathrm{TL}$, et al. Thymus-derived regulatory $\mathrm{T}$ cells contribute to tolerance to commensal microbiota. Nature. (2013) 497:258-62. doi: 10.1038/ nature12079

23. Gallegos AM, Bevan MJ. Central tolerance: good but imperfect. Immunol Rev. (2006) 209:290-6. doi: 10.1111/j.0105-2896.2006.00348.x

24. Kohler S, Thiel A. Life after the thymus: CD31+ and CD31human naive CD4+ T-cell subsets. Blood. (2009) 113:76974. doi: 10.1182/blood-2008-02-139154

25. Ravkov E, Slev P, Heikal N. Thymic output: assessment of CD4(+) recent thymic emigrants and T-Cell receptor excision circles in infants. Cytometry B Clin Cytom. (2017) 92:249-57. doi: 10.1002/cyto.b.21341 
26. van den Broek T, Borghans JAM, van Wijk F. The full spectrum of human naive $\mathrm{T}$ cells. Nat Rev Immunol. (2018) 18:363-73. doi: 10.1038/s41577-018-0001-y

27. Cicin-Sain L, Messaoudi I, Park B, Currier N, Planer S, Fischer M, et al. Dramatic increase in naive $\mathrm{T}$ cell turnover is linked to loss of naive $\mathrm{T}$ cells from old primates. Proc Natl Acad Sci U S A. (2007) 104:199605. doi: 10.1073/pnas.0705905104

28. Thome JJ, Grinshpun B, Kumar BV, Kubota M, Ohmura Y, Lerner $\mathrm{H}$, et al. Longterm maintenance of human naive $\mathrm{T}$ cells through in situ homeostasis in lymphoid tissue sites. Sci Immunol. (2016) 1:eaah6506. doi: 10.1126/sciimmunol.aah6506

29. Fagnoni FF, Vescovini R, Passeri G, Bologna G, Pedrazzoni M, Lavagetto G, et al. Shortage of circulating naive CD8(+) $\mathrm{T}$ cells provides new insights on immunodeficiency in aging. Blood. (2000) 95:2860-8. doi: 10.1182/blood.V95.9.2860.009k35 _2860_2868

30. Cicin-Sain L, Smyk-Pearson S, Currier N, Byrd L, Koudelka $\mathrm{C}$, Robinson $\mathrm{T}$, et al. Loss of naive $\mathrm{T}$ cells and repertoire constriction predict poor response to vaccination in old primates. J Immunol. (2010) 184:6739-45. doi: 10.4049/jimmunol.09 04193

31. Goggins JA, Kurtz JR, McLachlan JB. Control of persistent salmonella infection relies on constant thymic output despite increased peripheral antigen-specific $\mathrm{T}$ cell immunity. Pathogens. (2020) 9:605. doi: 10.3390/pathogens9080605

32. Betjes MG, Litjens NH. Chronic kidney disease and premature ageing of the adaptive immune response. Curr Urol Rep. (2015) 16:471. doi: 10.1007/s11934-014-0471-9

33. Betjes MGH, Langerak AW, Klepper M, Litjens NHR. A very low thymus function identifies patients with substantial increased risk for long-term mortality after kidney transplantation. Immun Ageing. (2020) 17:4. doi: 10.1186/s12979-020-00175-Z

34. Meijers RW, Litjens NH, de Wit EA, Langerak AW, van der Spek A, Baan CC, et al. Uremia causes premature ageing of the $\mathrm{T}$ cell compartment in end-stage renal disease patients. Immun Ageing. (2012) 9:19. doi: 10.1186/1742-4933-9-19

35. Thome JJ, Bickham KL, Ohmura Y, Kubota M, Matsuoka N, Gordon C, et al. Early-life compartmentalization of human $\mathrm{T}$ cell differentiation and regulatory function in mucosal and lymphoid tissues. Nat Med. (2016) 22:72-7. doi: 10.1038/nm.4008

36. Dedeoglu B, de Weerd AE, Huang L, Langerak AW, Dor FJ, Klepper $\mathrm{M}$, et al. Lymph node and circulating $\mathrm{T}$ cell characteristics are strongly correlated in end-stage renal disease patients, but highly differentiated $\mathrm{T}$ cells reside within the circulation. Clin Exp Immunol. (2017) 188:299310. doi: 10.1111/cei.12934

37. Raskova J, Czerwinski DK, Shea SM, Raska K, Jr. Cellular immunity and lymphocyte populations in developing uremia in the rat. J Exp Pathol. (1986) 2:229-45.

38. Cepeda S, Griffith AV. Thymic stromal cells: Roles in atrophy and ageassociated dysfunction of the thymus. Exp Gerontol. (2018) 105:1137. doi: 10.1016/j.exger.2017.12.022

39. Majumdar S, Adiga V, Raghavan A, Rananaware SR, Nandi D. Comparative analysis of thymic subpopulations during different modes of atrophy identifies the reactive oxygen species scavenger, $\mathrm{N}$-acetyl cysteine, to increase the survival of thymocytes during infection-induced and lipopolysaccharide-induced thymic atrophy. Immunology. (2019) 157:21-36. doi: 10.1111/imm.13043

40. Majumdar S, Nandi D. Thymic atrophy: experimental studies and therapeutic interventions. Scand J Immunol. (2018) 87:4-14. doi: $10.1111 /$ sji.12618

41. Paz-Miguel JE, Flores R, Sanchez-Velasco P, Ocejo-Vinyals G, Escribano de Diego J, Lopez de Rego J, et al. Reactive oxygen intermediates during programmed cell death induced in the thymus of the Ts(1716)65Dn mouse, a murine model for human Down's syndrome. I Immunol. (1999) 163:5399-410.

42. Venet F, Monneret G. Advances in the understanding and treatment of sepsis-induced immunosuppression. Nat Rev Nephrol. (2018) 14:12137. doi: $10.1038 /$ nrneph.2017.165
43. Venet F, Rimmele T, Monneret G. Management of SepsisInduced Immunosuppression. Crit Care Clin. (2018) 34:97106. doi: 10.1016/j.ccc.2017.08.007

44. Courivaud C, Bamoulid J, Crepin T, Gaiffe E, Laheurte C, Saas $\mathrm{P}$, et al. Pre-transplant thymic function predicts is associated with patient death after kidney transplantation. Front Immunol. (2020) 11:1653. doi: 10.3389/fimmu.2020.01653

45. Johnstone J, Parsons R, Botelho F, Millar J, McNeil S, Fulop T, et al. Tcell phenotypes predictive of frailty and mortality in elderly nursing home residents. J Am Geriatr Soc. (2017) 65:153-9. doi: 10.1111/jgs.14507

46. Reynolds CA, Tan Q, Munoz E, Jylhävä J, Hjelmborg J, Christiansen $\mathrm{L}$, et al. A decade of epigenetic change in aging twins: genetic and environmental contributions to longitudinal DNA methylation. Aging Cell. (2020) 19:e13197. doi: 10.1111/acel.13197

47. Tan Q, Heijmans BT, Hjelmborg JV, Soerensen M, Christensen K, Christiansen L. Epigenetic drift in the aging genome: a ten-year follow-up in an elderly twin cohort. Int J Epidemiol. (2016) 45:114658. doi: 10.1093/ije/dyw132

48. Saule P, Trauet J, Dutriez V, Lekeux V, Dessaint JP, Labalette M. Accumulation of memory $\mathrm{T}$ cells from childhood to old age: central and effector memory cells in $\mathrm{CD} 4(+)$ versus effector memory and terminally differentiated memory cells in CD8(+) compartment. Mech Ageing Dev. (2006) 127:27481. doi: 10.1016/j.mad.2005.11.001

49. Brenchley JM, Karandikar NJ, Betts MR, Ambrozak DR, Hill BJ, Crotty LE, et al. Expression of CD57 defines replicative senescence and antigeninduced apoptotic death of CD8+ T cells. Blood. (2003) 101:271120. doi: 10.1182/blood-2002-07-2103

50. Hove-Skovsgaard M, Zhao Y, Tingstedt JL, Hartling HJ, Thudium RF, Benfield $\mathrm{T}$, et al. Impact of age and HIV status on immune activation, senescence and apoptosis. Front Immunol. (2020) 11:583569. doi: 10.3389/fimmu.2020.583569

51. Gindin Y, Gaggar A, Lok AS, Janssen HLA, Ferrari C, Subramanian GM, et al. DNA methylation and immune cell markers demonstrate evidence of accelerated aging in patients with chronic HBV or HCV, with or without HIV co-infection. Clin Infect Dis. (2020). doi: 10.1093/cid/ciaa1371. [Epub ahead of print].

52. Hadrup SR, Strindhall J, Kollgaard T, Seremet T, Johansson B, Pawelec $\mathrm{G}$, et al. Longitudinal studies of clonally expanded CD8 T cells reveal a repertoire shrinkage predicting mortality and an increased number of dysfunctional cytomegalovirus-specific T cells in the very elderly. J Immunol. (2006) 176:2645-53. doi: 10.4049/jimmunol.176.4.2645

53. Ahmed M, Lanzer KG, Yager EJ, Adams PS, Johnson LL, Blackman MA. Clonal expansions and loss of receptor diversity in the naive CD8 T cell repertoire of aged mice. J Immunol. (2009) 182:78492. doi: 10.4049/jimmunol.182.2.784

54. Naylor K, Li G, Vallejo AN, Lee WW, Koetz K, Bryl E, et al. The influence of age on T cell generation and TCR diversity. J Immunol. (2005) 174:744652. doi: 10.4049/jimmunol.174.11.7446

55. Huang L, Betjes MGH, Klepper M, Langerak AW, Baan CC, Litjens NHR. end-stage renal disease causes skewing in the TCR vbetarepertoire primarily within CD8(+) T cell subsets. Front Immunol. (2017) 8:1826. doi: 10.3389/fimmu.2017.01826

56. Huang L, Langerak AW, Wolvers-Tettero IL, Meijers RW, Baan CC, Litjens $\mathrm{NH}$, et al. End stage renal disease patients have a skewed $\mathrm{T}$ cell receptor Vbeta repertoire. Immun Ageing. (2015) 12:28. doi: 10.1186/s12979-015-0055-7

57. Callard RE, Stark J, Yates AJ. Fratricide: a mechanism for $\mathrm{T}$ memory-cell homeostasis. Trends Immunol. (2003) 24:3705. doi: 10.1016/S1471-4906(03)00164-9

58. Naismith E, Pangrazzi L, Grasse M, Keller M, Miggitsch C, Weinberger $\mathrm{B}$, et al. Peripheral antibody concentrations are associated with highly differentiated $\mathrm{T}$ cells and inflammatory processes in the human bone marrow. Immun Ageing. (2019) 16:21. doi: 10.1186/s12979-019-0161-z

59. Nanda NK. Tissue-resident memory $T$ cells: sheltering-inplace for host defense. Crit Rev Immunol. (2020) 40:42340. doi: 10.1615/CritRevImmunol.2020035522

60. Schmidt A, Lapuente D. T cell immunity against influenza: the long way from animal models towards a real-life universal flu vaccine. Viruses. (2021) 13:199. doi: 10.3390/v13020199 
61. Laidlaw BJ, Zhang N, Marshall HD, Staron MM, Guan T, Hu Y, et al. $\mathrm{CD} 4+\mathrm{T}$ cell help guides formation of CD103+ lung-resident memory CD8+ T cells during influenza viral infection. Immunity. (2014) 41:63345. doi: 10.1016/j.immuni.2014.09.007

62. Goronzy JJ, Fulbright JW, Crowson CS, Poland GA, O'Fallon WM, Weyand CM. Value of immunological markers in predicting responsiveness to influenza vaccination in elderly individuals. J Virol. (2001) 75:121827. doi: 10.1128/JVI.75.24.12182-12187.2001

63. Saurwein-Teissl M, Lung TL, Marx F, Gschösser C, Asch E, Blasko I, et al. Lack of antibody production following immunization in old age: association with CD8(+)CD28(-) T cell clonal expansions and an imbalance in the production of Th1 and Th2 cytokines. J Immunol. (2002) 168:58939. doi: 10.4049/jimmunol.168.11.5893

64. Betjes MGH, Litjens NHR. High numbers of differentiated CD28null CD8 + $\mathrm{T}$ cells are associated with a lowered risk for late rejection and graft loss after kidney transplantation. PLoS ONE. (2020) 15:e0228096. doi: 10.1371/journal.pone.0228096

65. Dedeoglu B, Meijers RW, Klepper M, Hesselink DA, Baan CC, Litjens $\mathrm{NH}$, et al. Loss of CD28 on peripheral $\mathrm{T}$ cells decreases the risk for early acute rejection after kidney transplantation. PLoS ONE. (2016) 11:e0150826. doi: 10.1371/journal.pone.0150826

66. Morris AB, Farley CR, Pinelli DF, Adams LE, Cragg MS, Boss JM, et al. Signaling through the inhibitory $\mathrm{Fc}$ receptor $\mathrm{Fc} \gamma \mathrm{RIIB}$ induces CD8(+) $\mathrm{T}$ cell apoptosis to limit $\mathrm{t}$ cell immunity. Immunity. (2020) 52:136-50. e6. doi: 10.1016/j.immuni.2019.12.006

67. Betjes MG. Clinical consequences of circulating CD28-negative $\mathrm{T}$ cells for solid organ transplantation. Transpl Int. (2016) 29:274-84. doi: 10.1111/tri.12658

68. Rocamora-Reverte L, Melzer FL, Würzner R, Weinberger B. The complex role of regulatory $\mathrm{T}$ cells in immunity and aging. Front Immunol. (2020) 11:616949. doi: 10.3389/fimmu.2020.616949

69. Litjens NH, Boer K, Zuijderwijk JM, Klepper M, Peeters AM, Verschoor W, et al. Natural regulatory $\mathrm{T}$ cells from patients with end-stage renal disease can be used for large-scale generation of highly suppressive alloantigen-specific Tregs. Kidney Int. (2017) 91:1203-13. doi: 10.1016/j.kint.2016.09.043

70. Zook EC, Krishack PA, Zhang S, Zeleznik-Le NJ, Firulli AB, Witte PL, et al. Overexpression of Foxn1 attenuates age-associated thymic involution and prevents the expansion of peripheral CD4 memory T cells. Blood. (2011) 118:5723-31. doi: 10.1182/blood-2011-03-342097

71. Sato K, Kato A, Sekai M, Hamazaki Y, Minato N. Physiologic thymic involution underlies age-dependent accumulation of senescence-associated $\mathrm{CD} 4(+) \quad \mathrm{T}$ cells. J Immunol. (2017) 199:138-48. doi: 10.4049/jimmunol.1602005

72. Sauce D, Larsen M, Fastenackels S, Duperrier A, Keller M, GrubeckLoebenstein B, et al. Evidence of premature immune aging in patients thymectomized during early childhood. J Clin Invest. (2009) 119:30708. doi: 10.1172/JCI39269

73. Litjens NH, de Wit EA, Betjes MG. Differential effects of age, cytomegalovirus-seropositivity and end-stage renal disease (ESRD) on circulating $\mathrm{T}$ lymphocyte subsets. Immun Ageing. (2011) 8:2. doi: 10.1186/1742-4933-8-2

74. Huang L, Litjens NHR, Kannegieter NM, Klepper M, Baan CC, Betjes MGH. pERK-dependent defective TCR-mediated activation of CD4(+) $\mathrm{T}$ cells in end-stage renal disease patients. Immun Ageing. (2017) 14:14. doi: 10.1186/s12979-017-0096-1

75. Li G, Yu M, Lee WW, Tsang M, Krishnan E, Weyand CM, et al. Decline in miR-181a expression with age impairs $\mathrm{T}$ cell receptor sensitivity by increasing DUSP6 activity. Nat Med. (2012) 18:151824. doi: $10.1038 / \mathrm{nm} .2963$

76. Grasselli G, Zangrillo A, Zanella A, Antonelli M, Cabrini L, Castelli A, et al. Baseline characteristics and outcomes of 1591 patients infected with SARS-CoV-2 admitted to ICUs of the lombardy region, italy. JAMA. (2020) 323:1574-81. doi: 10.1001/jama.2020.5394

77. Council E-E, Group EW. Chronic kidney disease is a key risk factor for severe COVID-19: a call to action by the ERA-EDTA. Nephrol Dial Transplant. (2021) 36:87-94. doi: 10.1093/ndt/gfaa314

78. Rydyznski Moderbacher C, Ramirez SI, Dan JM, Grifoni A, Hastie KM, Weiskopf D, et al. Antigen-specific adaptive immunity to SARS-CoV-2 in acute COVID-19 and associations with age and disease severity. Cell. (2020) 183:996-1012. e19. doi: 10.1016/j.cell.2020.09.038

79. García LF. Immune response, inflammation, and the clinical spectrum of COVID-19. Front Immunol. (2020) 11:1441. doi: 10.3389/fimmu.2020.01441

80. Huang C, Wang Y, Li X, Ren L, Zhao J, Hu Y, et al. Clinical features of patients infected with (2019) novel coronavirus in Wuhan, China. Lancet. (2020) 395:497-506. doi: 10.1016/S0140-6736(20)30183-5

81. Vabret N, Britton GJ, Gruber C, Hegde S, Kim J, Kuksin M, et al. Immunology of COVID-19: current state of the science. Immunity. (2020) 52:910-41.

82. Hoagland DA, Møller R, Uhl SA, Oishi K, Frere J, Golynker I, et al. Leveraging the antiviral type I interferon system as a first line of defense against SARS-CoV-2 pathogenicity. Immunity. (2021) 54:55770. doi: 10.1016/j.immuni.2021.01.017

83. Chen G, Wu D, Guo W, Cao Y, Huang D, Wang H, et al. Clinical and immunological features of severe and moderate coronavirus disease 2019. J Clin Invest. (2020) 130:2620-9. doi: 10.1172/JCI137244

84. Qin C, Zhou L, Hu Z, Zhang S, Yang S, Tao Y, et al. Dysregulation of immune response in patients with coronavirus 2019 (COVID-19) in Wuhan, China. Clin Infect Dis. (2020) 71:762-8. doi: 10.1093/cid/ciaa248

85. Wang F, Nie J, Wang H, Zhao Q, Xiong Y, Deng L, et al. Characteristics of peripheral lymphocyte subset alteration in COVID-19 pneumonia. J Infect Dis. (2020) 221:1762-9. doi: 10.1093/infdis/jiaa150

86. Zheng M, Gao Y, Wang G, Song G, Liu S, Sun D, et al. Functional exhaustion of antiviral lymphocytes in COVID-19 patients. Cell Mol Immunol. (2020) 17:533-5. doi: 10.1038/s41423-020-0402-2

87. Wan S, Yi Q, Fan S, Lv J, Zhang X, Guo L, et al. Relationships among lymphocyte subsets, cytokines, and the pulmonary inflammation index in coronavirus (COVID-19) infected patients. Br J Haematol. (2020) 189:42837. doi: 10.1111/bjh.16659

88. De Biasi S, Meschiari M, Gibellini L, Bellinazzi C, Borella R, Fidanza $\mathrm{L}$, et al. Marked $\mathrm{T}$ cell activation, senescence, exhaustion and skewing towards TH17 in patients with COVID-19 pneumonia. Nat Commun. (2020) 11:3434. doi: 10.1038/s41467-020-17292-4

89. Liu J, Li S, Liu J, Liang B, Wang X, Wang H, et al. Longitudinal characteristics of lymphocyte responses and cytokine profiles in the peripheral blood of SARS-CoV-2 infected patients. EBioMedicine. (2020) 55:102763. doi: 10.1016/j.ebiom.2020.102763

90. Betjes MG, de Wit EE, Weimar W, Litjens NH. Circulating pro-inflammatory CD4posCD28null T cells are independently associated with cardiovascular disease in ESRD patients. Nephrol Dial Transplant. (2010) 25:36406. doi: $10.1093 / \mathrm{ndt} / \mathrm{gfq} 203$

91. Meijers RW, Litjens NH, Hesselink DA, Langerak AW, Baan CC, Betjes MG. Primary cytomegalovirus infection significantly impacts circulating $\mathrm{T}$ cells in kidney transplant recipients. Am J Transplant. (2015) 15:314356. doi: 10.1111/ajt.13396

92. Vescovini R, Biasini C, Fagnoni FF, Telera AR, Zanlari L, Pedrazzoni $\mathrm{M}$, et al. Massive load of functional effector CD4+ and CD8+ T cells against cytomegalovirus in very old subjects. J Immunol. (2007) 179:428391. doi: 10.4049/jimmunol.179.6.4283

93. Redeker A, Remmerswaal EBM, van der Gracht ETI, Welten SPM, Hollt $\mathrm{T}$, Koning F, et al. The contribution of cytomegalovirus infection to immune senescence is set by the infectious dose. Front Immunol. (2017) 8:1953. doi: 10.3389/fimmu.2017.01953

94. Betjes MG, Huisman M, Weimar W, Litjens NH. Expansion of cytolytic CD4+CD28- T cells in end-stage renal disease. Kidney Int. (2008) 74:7607. doi: 10.1038/ki.2008.301

95. Huang L, Langerak AW, Baan CC, Litjens NH, Betjes MG. Latency for cytomegalovirus impacts $\mathrm{T}$ cell ageing significantly in elderly end-stage renal disease patients. Clin Exp Immunol. (2016) 186:239-48. doi: 10.1111/cei.12846

96. Zhang X, Feng X, Cai W, Liu T, Liang Z, Sun Y, et al. Chemokine CX3CL1 and its receptor CX3CR1 are associated with human atherosclerotic lesion volnerability. Thromb Res. (2015) 135:1147-53. doi: 10.1016/j.thromres.2015.03.020

97. Betjes MG, Meijers RW, de Wit LE, Litjens NH. A killer on the road: circulating $\mathrm{CD} 4(+) \mathrm{CD} 28$ null $\mathrm{T}$ cells as cardiovascular risk factor in ESRD patients. J Nephrol. (2012) 25:183-91. doi: 10.5301/ jn. 5000057 
98. Betjes MG, Weimar W, Litjens NH. Circulating CD4(+)CD28null T cells may increase the risk of an atherosclerotic vascular event shortly after kidney transplantation. J Transplant. (2013) 2013:841430. doi: 10.1155/2013/841430

99. Xiong Y, Liu Y, Cao L, Wang D, Guo M, Jiang A, et al. Transcriptomic characteristics of bronchoalveolar lavage fluid and peripheral blood mononuclear cells in COVID-19 patients. Emerg Microbes Infect. (2020) 9:761-70. doi: 10.1080/22221751.2020.1747363

100. Zhou Z, Ren L, Zhang L, Zhong J, Xiao Y, Jia Z, et al. Heightened Innate Immune Responses in the Respiratory Tract of COVID-19 Patients. Cell Host Microbe. (2020) 27:883-90. e2 doi: 10.1016/j.chom.2020.04.017

101. Ronit A, Berg RMG, Bay JT, Haugaard AK, Ahlström MG, Burgdorf KS, et al. Compartmental immunophenotyping in COVID-19 ARDS: a case series. $J$ Allergy Clin Immunol. (2021) 147:81-91. doi: 10.1016/j.jaci.2020.09.009

102. Liao M, Liu Y, Yuan J, Wen Y, Xu G, Zhao J, et al. Single-cell landscape of bronchoalveolar immune cells in patients with COVID-19. Nat Med. (2020) 26:842-4. doi: 10.1038/s41591-020-0901-9

103. Group WHOREAfC-TW, Sterne JAC, Murthy S, Diaz JV, Slutsky AS, Villar $\mathrm{J}$, et al. Association between administration of systemic corticosteroids and mortality among critically ill patients with covid-19: a meta-analysis. JAMA. (2020) 324:1330-41.

104. Belli LS, Fondevila C, Cortesi PA, Conti S, Karam V, Adam R, et al. Protective role of tacrolimus, deleterious role of age and comorbidities in liver transplant recipients with Covid-19: results from the ELITA/ELTR multi-center European study. Gastroenterology. (2020) 160:1151-63. doi: 10.1053/j.gastro.2020.11.045

105. Betjes MG. Uremia-associated ageing of the thymus and adaptive immune responses. Toxins. (2020) 12:224. doi: 10.3390/toxins12040224

106. Thomas R, Wang W, Su DM. Contributions of age-related thymic involution to immunosenescence and inflammaging. Immun Ageing. (2020) 17:2. doi: 10.1186/s12979-020-0173-8

107. Cheng L, Guo J, Sun L, Fu J, Barnes PF, Metzger D, et al. Postnatal tissuespecific disruption of transcription factor FoxN1 triggers acute thymic atrophy. J Biol Chem. (2010) 285:5836-47. doi: 10.1074/jbc.M109.072124

108. Sun L, Guo J, Brown R, Amagai T, Zhao Y, Su DM. Declining expression of a single epithelial cell-autonomous gene accelerates age-related thymic involution. Aging Cell. (2010) 9:347-57. doi: 10.1111/j.1474-9726.2010.00559.x
109. Chu YW, Memon SA, Sharrow SO, Hakim FT, Eckhaus M, Lucas PJ, et al. Exogenous IL-7 increases recent thymic emigrants in peripheral lymphoid tissue without enhanced thymic function. Blood. (2004) 104:1110-9. doi: 10.1182/blood2003-10-3635

110. Henson SM, Snelgrove R, Hussell T, Wells DJ, Aspinall R. An IL-7 fusion protein that shows increased thymopoietic ability. J Immunol. (2005) 175:4112-8. doi: 10.4049/jimmunol.175.6.4112

111. Meijers RW, Litjens NH, de Wit EA, Langerak AW, Baan CC, Betjes MG. Uremia-associated immunological aging is stably imprinted in the T-cell system and not reversed by kidney transplantation. Transpl Int. (2014) 27:1272-84. doi: 10.1111/tri.12416

112. Yang H, Youm YH, Vandanmagsar B, Rood J, Kumar KG, Butler AA, et al. Obesity accelerates thymic aging. Blood. (2009) 114:380312. doi: 10.1182/blood-2009-03-213595

113. Jongbloed F, Meijers RWJ, JNM IJ, Klaassen RA, Dolle MET, van den Berg $\mathrm{S}$, et al. Effects of bariatric surgery on telomere length and T-cell aging. Int J Obes. (2019) 43:2189-99. doi: 10.1038/s41366-019-0351-y

114. Duggal NA, Niemiro G, Harridge SDR, Simpson RJ, Lord JM. Can physical activity ameliorate immunosenescence and thereby reduce age-related multi-morbidity? Nat Rev Immunol. (2019) 19:563-72. doi: 10.1038/s41577-019-0177-9

115. Duggal NA, Pollock RD, Lazarus NR, Harridge S, Lord JM. Major features of immunesenescence, including reduced thymic output, are ameliorated by high levels of physical activity in adulthood. Aging Cell. (2018) 17:e12750. doi: 10.1111/acel.12750

Conflict of Interest: The author declares that the research was conducted in the absence of any commercial or financial relationships that could be construed as a potential conflict of interest.

Copyright (C) 2021 Betjes. This is an open-access article distributed under the terms of the Creative Commons Attribution License (CC BY). The use, distribution or reproduction in other forums is permitted, provided the original author(s) and the copyright owner(s) are credited and that the original publication in this journal is cited, in accordance with accepted academic practice. No use, distribution or reproduction is permitted which does not comply with these terms. 